\title{
САМОУБИЙСТВА СРЕДИ ВРАЧЕЙ И МЕДИЦИНСКИХ РАБОТНИКОВ: ОБЗОР АИТЕРАТУРЫ
}

\author{
А.В. Филоненко, А.В. Голенков, В.А. Филоненко, Ф.В. Орлов, Е.С. Деомидов \\ ФГБОУ ВО “Чувашский государственный университет имени И.Н. УАьянова», г. Чебоксары, Россия \\ БУ "Республиканская детская клиническая больница", г. Чебоксары, Россия
}

\section{SUICIDES AMONG DOCTORS AND HEALTH CARE WORKERS: REVIEW OF LITERATURE}

\author{
A.V. Filonenko, A.V. Golenkov, V.A. Filonenko, \\ F.V. Orlov, E.S. Deomidov
}

I.N. Ulianov Chuvash State University, Cheboksary, Russia

Контактная информация:

Фимоненко А^ександр Валентинович - кандидат медицинских наук, доцент (SPIN-код: 8545-8680; ORCID iD: 0000-0001-7236-5410). Место работы и должность: доцент кафедры педиатрии и детской хирургии ФГБОУ ВО "Чувашский государственный университет им. И.Н. УАьянова", БУ «Республиканская детская клиническая больница». Адрес: Россия, г. Чебоксары, Московский проспект, 15. Темефон: +7 (905) 197-63-81, электронный адрес: filonenko56@mail.ru

Голенков Андрей Васимьевич - доктор медицинских наук, профессор (SPIN-код: 7936-1466; ORCID iD: 0000-0002-3799-0736; Researcher ID: C-4806-2019). Место работы и должность: заведующий кафедрой психиатрии, медицинской психологии и неврологии ФГБОУ ВО «Чувашский государственный университет им. И.Н. УАьянова". Адрес: г. Чебоксары, ум. Пирогова, 6. Телефон: +7 (905)197-35-25, эмектронный адрес: golenkovav@inbox.ru

Фимоненко Вера Александровна - главный научный сотрудник (SPIN-код:_4288-3913; ORCID iD: 0000-00033872-5923). Место работы: отдем международного образования ФГБОУ ВО “Чувашский государственный университет им. И.Н. УАьянова". Адрес: Россия, г. Чебоксары, Московский проспект, 15. Телефон: +7 (903) 063-36-06, эмектронный адрес: filvee@mail.ru

Орлов Федор Витальевич - кандидат медицинских наук, доцент (SPIN-код: 5604-0041; ORCID iD: 0000-00028772-4428). Место работы и должность: доцент кафедры психиатрии, медицинской психологии и неврологии ФГБОУ ВО “Чувашский государственный университет им. И.Н. УАьянова", БУ "Республиканская психиатрическая больница". Адрес: Россия, г. Чебоксары, ум. Пирогова, 6. Темефон: +7 (903) 358-01-06, эмектронный адрес: orlovf@yandex.ru

Деомидов Евгений Сергеевич - кандидат медицинских наук, доцент (SPIN-код: 9811-9509; ORCID iD: 00000001-8107-3671). Место работы и должность: доцент кафедры психиатрии, медицинской психологии и неврологии ФГБОУ ВО “Чувашский государственный университет им. И.Н. УАьянова». Адрес: Россия, г. Чебоксары, ул. Пирогова, 6. Темефон: +7 (927) 845-99-97, электронный адрес: neurokaf@yandex.ru

\section{Contact Information:}

Filonenko Aleksandr Valentinovich - Candidate of Medical Sciences (SPIN-code: 8545-8680; ORCID iD: 0000-00017236-5410). Place of work and position: Assistant Professor of the Department of Pediatrics and Pediatric Surgery, I.N. Ulianov Chuvash State University. Address: Cheboksary, 6 Pirogov Str. Republican Children's Clinical Hospital. Address: Cheboksary, Moskovsky Prospect, 15. Tel.: +7 (905) 197-63-81, e-mail: filonenko56@mail.ru

Golenkov Andrei Vasilievich - Doctor of Medical Sciences, Professor (SPIN-code: 7936-1466; ORCID iD: 0000-00023799-0736; Researcher ID: C-4806-2019). Place of work and position: Head of the Department of Psychiatrics, Medical Psychology and Neurology, I.N. Ulianov Chuvash State University. Address: Cheboksary, 6 Pirogov Str. Tel.: (905)197-3525, e-mail: golenkovav@inbox.ru

Filonenko Vera Aleksandrovna - Head of the International education Office (SPIN-code: 4288-3913; ORCID iD: 00000003-3872-5923). Place of work and position: International Affairs Department, I.N. Ulianov Chuvash State University. Address: Cheboksary, Moskovsky Prospect, 15. Tel.: +7 (903) 063-36-06, e-mail: filvee@mail.ru

Orlov Fedor Vitalievich - Candidate of Medical Sciences (SPIN-code: 5604-0041; ORCID iD: 0000-0002-8772-4428). Place of work and position: Assistant Professor of the Department of Psychiatrics, Medical Psychology and Neurology, I.N. Ulianov Chuvash State University, Republican Psychiatric Hospital. Address: Cheboksary, 6 Pirogov Str. Tel.: +7 (903) 358-01-06, e-mail: orlovf@yandex.ru

Deomidov Evgeni Sergeevich - Candidate of Medical Sciences (SPIN-code: 9811-9509; ORCID iD: 0000-0001-81073671). Place of work and position: Assistant Professor of the Department of Psychiatrics, Medical Psychology and Neurology, I.N. Ulianov Chuvash State University. Address: Cheboksary, 6 Pirogov Str. Tel.: +7 (927) 845-99-97, e-mail: neurokaf@yandex.ru

По оценкам Всемирной Организации Здравоохранения, на самоубийство (СУ) приходится почти $1,5 \%$ всех смертей в мире, и оно входит в число 20 основных причин смерти населения. Суицидальное поведение заметно различается между полами, возрастными и профессиональными группами, что подчеркивает его вероятную этиологическую неоднородность. Целью исследования явилось обобщение сведений о распространённости, факторах, связанных с риском СУ среди врачей и медработников, а также о путях предотвращении у них 
суицидального поведения. Результаты: По данным литературы, уровень СУ среди врачей и медработников в 1,5-4 раза выше, чем среди представителей ряда других профессий и населения в целом. Причём это характерно как для женщин, так и для мужчин, работающих в здравоохранении. Уровень СУ среди медработников со свободным доступом к лекарствам выше, чем среди тех, кто не имеет такой возможности. Не случайно, что отравление являются одним из основных способов СУ среди врачей и медработников (в 3-5 раз чаще, чем другие группы населения). По этому показателю данная профессиональная группа существенно отличается от популяции. Среди факторов, способствующих СУ у врачей и медработников, выделяют: стресс на рабочем месте, депрессивные состояния и другие психические расстройства (ПР), синдром эмоционального выгорания (СЭВ), низкую удовлетворённость от работы, ангедонию. Предпосылки к развитию депрессии прослеживаются со времени обучения в ВУЗе. Потом этому способствуют профессиональные стрессы, такие как длительный рабочий день, недосыпание, требования высокой степени профессионализма и ответственности за пациентов, ежедневные конфликты между этическими ценностями и экономическими целями, а также судебные иски о халатности (риски медицинских ошибок). В последние десятилетия работа врачей с пациентами стала более сложной из-за возросшей нагрузки, административных обязанностей и снижения автономии. СЭВ у врачей и медработников зависит: от специальности [чаще у неврологов (53-75\%), хирургов (46-47\%), акушергинекологов (45\%), пола (чаще у женщин-врачей - 50\%), еженедельной нагрузки (чем больше, тем СЭВ встречается чаще] и отсутствия уважения со стороны больных, администрации и коллег. Экономические вопросы, касающиеся стоимости лечения, снижение общественного имиджа и неуверенность в профессии, ответственность перед безнадежно больными пациентами, напряжённые межличностные отношения с коллегами влияют на восприятие удовлетворённости работой. Стратегией профилактики СУ у врачей и медработников являются раннее выявление и правильное лечение депрессивных расстройств (ПР), СЭВ, оптимизация межличностных отношений на работе и признание важности поддержки семьи (ближайшего окружения). Заключение. Суицидальное поведение считается предотвратимой причиной смерти. Своевременное психологическое и медикаментозное воздействие может способствовать его профилактике. Настороженность коллег о возможном СУ, социализация, поведенческое, суггестивное рефлексотерапевтическое пособие позволяют предотвратить реализацию суицидальных намерений у врачей и медработников. В России обсуждаемая в обзоре проблема пока мало изучена, хотя факторы, способствующие СУ, описаны в литературе. Поэтому есть все основания говорить о чрезвычайной актуальности суицидального поведения и его профилактике среди членов медицинского сообщества нашей страны.

Ключевые слова: самоубийство, врачи, медработники, факторы риска, профилактика

Самоубийство (СУ) является важной медикосоциальной проблемой, затрагивающей не только семью, родных, друзей и коллег суицидента, но и всё общество, принося социально-экономический ущерб. Несмотря на тенденцию снижения уровня СУ в России в последние годы, показатели суицидальной смертности, по-прежнему, удерживаются на достаточно высоком уровне. Суммарные годы потерянной трудоспособной жизни вследствие суицидов в 2009 г. в России составили 723 на 100000 населения трудоспособного возраста или $0,46 \%$ Валового внутреннего продукта. Суммарные потери вследствие суицидов составили 145,788 млрд руб. (4,6 млрд долларов) [1].

СУ - это десятая по значимости причина смерти для всех возрастов в 2016 г. 44965 завершённых СУ в США, что соответствует 123 смертям от СУ в день. Экономическая стоимость смерти от СУ в стране в 2013 г. оценивалась в 58,4 млрд долларов [2].

Суицидальное поведение заметно различается между полами, возрастными группами, профессиональной принадлежностью, географическими регионами и социально-политическими условиями и поразному ассоциируется с различными факторами риска, что подчеркивает вероятную этиологическую неоднородность [3]. Изучение связи СУ с родом занятий, влиянием социально-экономических, демографических и психиатрических различий, проведённого Е. Agerbo и соавт. в 3195 случаях, показало, что среди 55 исследо-
Suicide (SU) is an important medical and social problem affecting not only the family, relatives, friends and colleagues of a suicidal person, but also the whole society, causing social and economic damage. Despite the downward trend of SU rates in Russia in recent years, suicidal mortality rates still stay at a fairly high level. In 2009 the total years of lost working life due to suicides in Russia amounted to 723 per 100000 of working-age population or $0.46 \%$ of Gross Domestic Product. The total loss due to suicide rates was 145,788 billion rubles ( $\$ 4.6$ billion) [1].

$\mathrm{SU}$ is the tenth leading cause of death for all ages in 2016. 44.965 completed SU in the United States, corresponding to $123 \mathrm{SU}$ deaths per day. In 2013 the economic value of SU deaths in the country was estimated at 58.4 billion dollars [2]. Suicidal behavior varies markedly between sexes, age groups, occupational affiliation, geographic regions and socio-political conditions and is associated differently with different risk factors, highlighting the likely etiological heterogeneity [3]. The study of interrelation between SU and occupation, the influence of socio-economic, demographic and psychiatric differences, conducted by E. Agerbo et al. in 3195 cases, showed that among 55 professions the risk of SU ranged from 2.73 for doctors to 0.44 for 
ванных ими профессий риск СУ варьировал от 2,73 среди врачей до 0,44 среди архитекторов и инженеров. За исключением врачей и медсестер, СУ, связанные с конкретными профессиями, объясняются социальноэкономическими характеристиками. Бо̀льшая вероятность риска суицида врачей и медсестер связана со знаниями, которым они обладают, учитывая специфику профессии - это более частое использование самоотравления. Среди лиц, страдающих психическими расстройствами (ПР), профессия мало ассоциируется с СУ кроме врачей, чей риск в 3,62 раза выше. Бо̀льшая часть существенных различий в риске СУ по профессиям объясняется социально - экономическими условиями [4]. Вероятно, специфичные для профессии факторы могут объяснить повышенный уровень СУ, несмотря на хорошее физическое здоровье. Личность и самооценка врачей тесно связаны с их профессией.

Целью работы явилось обобщение сведений о распространённости, факторах, связанных с риском СУ среди врачей и медработников, а также о путях предотвращении суицидального поведения.

Распространённость самоубийств среди врачей и медработников.

СУ врачей является актуальной проблемой общественного здравоохранения, поскольку уровень СУ среди них выше, чем среди населения. Из всех профессий медики находятся на вершине риска смерти от СУ. A.J. Milner и соавт. [5] сообщают, что показатели СУ среди женщин медицинских специальностей в Австралии выше, чем среди женщин других профессий более, чем в 2,5 раза. У практикующих женщин-врачей отношение шансов (ОШ) - 2,52, у медсестёр и акушерок 2,65. Показатели СУ среди врачей-мужчин незначительно выше, чем для представителей других профессий, но уровень СУ среди мужчин-медбратьев и акушеров в 1,5 раза выше, чем среди мужчин, работающих вне медицинских профессий. Уровень СУ среди медработников, имеющих свободный доступ к лекарствам, отпускаемым по рецепту выше, чем среди медработников, не имеющих такой возможности.

E.S. Schernhammer и G.A. Colditz [6] подтверждают, что уровень СУ среди врачей чрезвычайно высок. Совокупный коэффициент СУ среди врачей-мужчин по сравнению с общей популяцией на $41 \%$ выше и составляет 1,41. Для женщин-врачей соотношение выше в 2,27 pasa.

Сравнения уровня СУ среди женщин-врачей и других женщин США показали, что ОШ достигает 4:1. Хотя такие сообщения и основаны на небольших группах (17-49 случаев), они часто приводятся в качестве доказательства высокой распространённости психопатологии среди женщин-врачей. По оценкам исследований E. Frank и A.D. Dingle [7], из выборки в 4100 женщин, 61 врач (1,5\%) пыталась покончить жизнь СУ, а $808(19,5 \%)$ имели в анамнезе депрессию. Лица, подвергшиеся сексуальному и домашнему насилию, куря- architects and engineers. With the exception of doctors and nurses, SU related to specific professions are explained by socio-economic characteristics. A high probability of suicide risk for doctors and nurses is associated with their specific professional knowledge - the use of self-poisoning is more frequent. Among people suffering from mental disorders (MD), profession is little associated with SU with the exception of doctors, whose risk is 3.62 times higher. Most of the significant differences in the risk of SU by profession are due to socioeconomic conditions [4]. Probably, profession-specific factors underlie the increased level of SU, despite good physical health. The personality and self-esteem of doctors are closely related to their profession. The aim of the work was to summarize information about the prevalence, factors associated with the risk of SU among doctors and health care workers, as well as the ways to prevent suicidal behavior.

Prevalence of suicide among doctors and health care workers.

Doctors' SU is an urgent public health problem, because the rate of SU for them is higher than among the general population. Of all professions, doctors are at the top of the risk of death from SU. A.J. Milner et al. [5] report that SU rates for women in medical professions in Australia are more than 2.5 times higher than among women in other professions. In practicing female doctors odds ratio $(\mathrm{OR})$ is 2.52 , in nurses and midwives it is 2.65. SU rates among male doctors are slightly higher than for other professions, but the SU rate for male nurses and midwives is 1.5 times higher than for men working in non-medical professions. The rate of SU for health professionals with easy access to prescription medicines is higher than for those in health professions without such access.

E.S. Schernhammer, G.A. Colditz [6] confirm that the rate of SU for doctors is extremely high. The cumulative SU rate for male doctors is $41 \%$ higher compared to the general population and amounts to 1.41 . For female doctors, the ratio is 2.27 times higher.

Comparison of the rate of SU for female doctors and other U.S. women showed that OR is 4:1. Although these reports are based on small groups (17-49 cases), they are often cited as the evidence of high prevalence of psychopathology among female health professionals. E. Frank, A.D. Dingle [7] estimate that, out of the sample of 4100 female doctors, $61(1,5 \%)$ tried to commit SU and 808 $(19,5 \%)$ had a history of depression. People who have been sexually and domestically abused, are addicted to cigarettes and alcohol, 
щие и злоупотребляющие алкоголем, с плохим психическим здоровьем, семейным анамнезом ПР, значительно чаще сообщают о попытках СУ и депрессии. Они также были характерны для одиноких, бездетных, имеющих дома оружие, лиц со стрессовой ситуацией в семье, злоупотребляющих алкоголем, с нарушениями физического здоровья, расстройством пищевого поведения, ожирением, синдромом хронической усталости и токсикоманией.

По сообщению J. Albuquerque и S. Tulk [8] CУ среди врачей является единственной причиной, превышающей смертность населения в целом. Врачи-мужчины на $40 \%$ чаще, чем обычные люди, совершают суицид, а риск для женщин-врачей более чем удвоен. Выделены некоторые особенности СУ врачей. Во-первых, СУ является профессиональным риском. Врачи учатся быть сильными и стойкими, оказывать помощь, а не получать её. Во-вторых, среди населения стран с правом владения огнестрельным оружием, наиболее распространённым средством СУ является самострел. Однако врачи предпочитают использовать для ухода из жизни самоотравление. В-третьих, суицидальные мысли начинают проявляться во время получения профессионального образования, особенно у студентовиностранцев. Согласно метаанализу 2016 г., распространённость суицидальных мыслей среди студентовмедиков составила 24\%. В-четвёртых, текущие намерения также связаны с повышенным уровнем предыдущих суицидальных мыслей. Так, при опросе 8000 врачей в Великобритании они чаще сообщали о суицидальных мыслях (намерениях). При отсутствии какихлибо жалоб на здоровье мысли о СУ высказывали $2,5 \%$, при их наличии показатель увеличивался до $9,3 \%$, и у тех, кто имел суицидальные намерения в прошлом - до 13,4\%. В-пятых, врачи-суициденты, как люди с проблемами психического здоровья, сталкиваются с нехваткой времени для обращения за медицинской помощью и отсутствием её дифференциации с учётом профессионального статуса. Они несут дополнительное бремя, связанное с конфиденциальностью и опасениями дискриминации, когда речь идёт об обращениях в лечебные учреждения по поводу депрессии (ПР) и различных суицидальных проявлений [8].

Способы суицида среди врачей и медработников.

В одной из ранних работ, посвящённых СУ среди врачей Северной Каролины (США), огнестрельное оружие и наркотики явились наиболее распространёнными методами для СУ [9]. СУ с применением огнестрельного оружия, по-видимому, остаются ведущей причиной смерти в США до настоящего времени. Известно, что показатели СУ среди населения, связанных с огнестрельным оружием в восемь раз выше в США по сравнению с другими странами мира [10]. Общие показатели смертности популяции, включая СУ, от огнестрельного оружия в 5-6 раз выше в странах с высоким и выше среднего уровнями дохода в Северной и have poor mental health and/or family history of $\mathrm{MD}$, are significantly more likely to report attempts of SU and depression. They were also characteristic for the single, childless, home-armed, family-stressed, alcohol abusers, with physical health problems, eating disorders, obesity, chronic fatigue syndrome and inhalant abuse.

According to J. Albuquerque, S. Talk [8] SU among doctors is the only cause of excess mortality in the general population. Male doctors are $40 \%$ more likely than ordinary people to commit suicide, and the risk for female doctors is more than doubled. Some features of doctors' SU are underlined. First, SU is a professional risk. Doctors learn to be strong and stout-hearted, to provide care, not to receive it. Second, among the population of the countries with the right to possess firearms, the most common method of $\mathrm{SU}$ is by the means of firearms. However, doctors prefer to use self-poisoning as a method of SU. Third, suicidal thoughts appear during vocational education, especially among foreign students. According to a meta-analysis of the year 2016, the prevalence of suicidal thoughts among medical students was $24 \%$. Fourth, current intentions are also associated with an increased level of previous suicidal thoughts. Thus, in a survey of 8000 doctors in the UK, they were more likely to report suicidal thoughts (intentions). If there were no health complaints, the thoughts about SU were expressed by $2.5 \%$, if they were present, the rate increased to $9.3 \%$, and for those who had suicidal intentions in the past - to $13.4 \%$. Fifth, doctors inclined to suicide, as people with mental health problems, have a lack of time to seek medical care and face with an absence of its differentiation based on professional status. They bear additional burden associated with confidentiality and fear of discrimination when it comes to treatment for major depression (MD) and various suicidal manifestations [8].

Methods of suicide among doctors and health care workers.

In one of the early works on SU among doctors in North Carolina (USA), firearms and drugs were the most common methods for SU [9]. SU with the use of firearms appears to remain the leading cause of death in the USA up to the present day. It is known that the rates of SU with the use of firearms among the population are eight times higher in the United States compared to other countries of the world [10]. Overall population mortality rates from firearms, including SU, are 5-6 times higher in high- and upper-middle-income countries in the Americas than in Europe or Oceania, and 95 times higher than in Asia; the 
Южной Америке, чем в Европе или Океании, и в 95 раз выше, чем в Азии; большинство смертей от огнестрельного оружия - это СУ (71\%) в странах с высоким уровнем доходов [11].

По данным 31636 жертв СУ K.J. Gold и соавт. [12], для 203 врачей (с правом владения огнестрельного оружия) применение самострела было наиболее распространённым методом (48\%), за которым следовали отравление $(23,5 \%)$, тупая травма $(14,5 \%)$ и асфиксия, включая повешение (14\%). Население (не врачи) также использовало огнестрельное оружие в качестве наиболее распространённого метода СУ (54\%); асфиксия была второй наиболее распространенной причиной смерти (22\%), за которой следовали отравление (18\%) и тупая травма (6\%). При этом врачи США с завершённым суицидом в 20-40 раз чаще принимали бензодиазепины или антипсихотические средства до смерти, чем население в целом, а также в три раза чаще испытывали проблемы на работе. Особый тревожный аспект СУ врача заключается в том, что знания фармакодинамики и дозировок препаратов повышают вероятность завершённой попытки СУ [13].

В Европейских странах (Нидерланды, Германия, Норвегия, Дания) врачи обоих полов часто использовали лекарства в качестве предпочтительного метода СУ, причём в два раза чаще, чем люди в общей популяции [14]. Лекарственные (психотропные) средства медработниками принимались перорально (в 29\% случаев) и путём инфузии / инъекционно ( $18 \%$; у врачей такой путь введения составлял 58\%). Из других методов СУ среди врачей и медработников использовалось повешение $(13 \%)$, отравление цианидом $(10 \%)$, падение с высоты $(10 \%)$ и утопление $(8 \%)$. Среди населения лидировало повешение (32\%), пероральный приём лекарств $(16 \%)$, падение с высоты (13\%), самострел (9\%), утопление (8\%) и железнодорожные СУ (7\%) [15].

В странах Азии из методов СУ у тайских врачей встречались повешение, самострел, внутривенные инъекции лекарственных средств, падение с высоты, передозировка препаратами [16]. На Тайване основными методами СУ врачей были повешение (удушение), утопление, падения с высоты, сжигание угля (отравление угарным газом в комнате) и отравление наркотиками [17].

В Новой Зеландии в течение 30 лет (1973-2004 гг.) высокие показатели СУ коррелировали с доступом к конкретным методам СУ и знакомству с ними. Так медсестры, врачи и фармацевты чаще прибегали к отравлению лекарственными средствами соответственно в три, четыре и пять раз чаще, чем люди других профессий. Оказалось, что доступ к сильнодействующим препаратам повлиял на выбранный метод СУ [18].

На судебно-медицинской экспертизе среди 9 случаев СУ врачей (возраст 30-69 лет; медиана - 41 год; мужчин: женщин $=3: 1)$ в Южной Австралии в течение 14-лет (с января 1997 г. по март 2011 г.) выявлено сле- majority of deaths from firearms are SU (71\%) in high-income countries [11].

K.J. Gould et al. [12] report that among 31.636 SU victims, for 203 doctors (with the right of possession of firearms) the most common method (48\%) was firearms, followed by poisoning $(23.5 \%)$, blunt trauma $(14.5 \%)$, and asphyxia, including hanging $(14 \%)$. The population (not doctors) also used firearms as the most common SU method (54\%); asphyxia was the second most common cause of death $(22 \%)$, followed by poisoning $(18 \%)$ and blunt trauma (6\%). At the same time, U.S. doctors with completed suicide were 20-40 times more likely to take benzodiazepines or antipsychotics before death than the general population, and three times more likely to experience problems at work. A disturbing aspect of doctors' $\mathrm{SU}$ is that the knowledge of pharmacodynamics and dosages of drugs increase the probability of a completed attempt of SU [13].

In European countries (the Netherlands, Germany, Norway, Denmark), doctors of both sexes often used medicinal preparations as the preferred method of SU, and twice as often as people in the general population [14]. Medicinal (psychotropic) preparations were taken orally (in 29\% of cases) and through an infusion/injection (18\%; in doctors - 58\%). Other SU methods used by doctors and health care workers included hanging (13\%), cyanide poisoning (10\%), high fall (10\%) and drowning $(8 \%)$. Hanging $(32 \%)$, oral medication $(16 \%)$, high fall (13\%), firearms $(9 \%)$, drowning $(8 \%)$ and railway SU (7\%) were the leaders among the population [15].

In Asia Thai doctors used such SU methods as hanging, firearms, intravenous injections of medicinal preparations, high fall, drug overdose [16]. In Taiwan, the main methods of doctors' SU were hanging (strangulation), drowning, jumping from a height, burning coal (carbon monoxide poisoning in the room) and drug poisoning [17].

In New Zealand, for 30 years (19732004), high SU rates correlated with access to and familiarity with specific SU methods. Thus nurses, doctors, and pharmacists were three, four, and five times more likely to resort to drug poisoning than people in other professions. It turned out that access to strong drugs influenced the chosen SU method [18].

The forensic examination of nine cases of doctors' SU (age 30-69 years; median-41 years; men: women $=3: 1$ ) in South Australia for 14 years (from January 1997 to March 2011) revealed the following: eight (88.9\%) physicians died from fatal medication (intravenous injection was the preferred method in 
дующее: восемь $(88,9 \%)$ медиков умерло от смертельного приёма лекарств (внутривенное их введение было предпочтительным методом в 7 случаях), в одном было зарегистрировано падение (прыжок) с высокого здания. Депрессии и суицидальные мысли отмечены в 6 случаях $(66,7 \%)$. Среди населения были распространены повешение, отравление угарным газом и огнестрельные ранения. Доказано, что наличие доступа и знание летальных эффектов лекарственных средств являются важными факторами, определяющими выбор методов СУ. Поэтому доступность к лекарствам должна тщательно контролироваться у врачей и медработников, имеющих в анамнезе депрессии и токсикомании [19].

С течением времени происходят изменения в распространённости СУ и используемых для этого методов. Отравление лекарственными и другими веществами представляет собой не самый эффективный способ добровольного ухода из жизни. Однако наличие доступа к лекарственным средствам и знания об их токсичности и механизмах действия остаётся существенным фактором (с высокой долей летальных исходов) для выбора врачами и медиками отравления (передозировка медикаментами) как одного из основных способов СУ.

Депрессия как предиктор суицида в профессии.

СУ почти всегда является результатом отсутствия или неадекватного лечения депрессии или другого ПР [20]. Предполагается, что проявления депрессии могут закладываться в раннем детстве. А. Sourander и соавт. [21] выяснено, что большинство мужчин, которые совершили или предприняли попытки СУ, имели психиатрические проблемы в возрасте до 8 лет. Это указывает на особую склонность, которая сохраняется в течение всей их жизни. СУ женщины не прогнозируется психопатологическими расстройствами в этом возрасте. Результаты дают дополнительные основания важности раннего выявления и лечения психиатрических проблем у врачей-мужчин.

Врачи и медработники на всех этапах своей карьеры имеют более высокий (в два раза) уровень депрессии, чем население в целом (39\% врачей в США). Около 400 врачей завершают жизнь СУ каждый год.

Распространённость депрессии составляет $27 \%$ у студентов-медиков, $29 \%$ у врачей-ординаторов и до $60 \%$ у практикующих врачей [22]. Высокий профессиональный стресс и утомление среди врачей приводят к проблемам со сном, беспокойству, депрессии и СУ [23].

По наблюдениям W. Wurm и соавт. [24] из обследованных 5897 врачей 10,3\% страдали депрессией: $0,9 \%$ - в лёгкой степени, $2,3 \%$ - в умеренной и $7,2 \%$ - в тяжёлой. У врачей с депрессией в 87,5\% случаев также обнаруживались симптомы выгорания. Доля врачей, страдающих депрессией, увеличилась в зависимости от степени выгорания (при лёгкой - 6,8\%, средней $20,2 \%$, тяжёлой - 53,6\%). Следствием бремени депрессии является высокая распространённость СУ, при этом общий коэффициент СУ составил 1,41 для муж- seven cases), in one case a fall (jump) from a high building was recorded. Depression and suicidal thoughts were reported in six cases $(66.7 \%)$. Hanging, carbon monoxide poisoning and gunshot wounds were common among the population. It is proved that availability of access and knowledge of lethal effects of medicinal products are important factors determining the choice of SU methods. Therefore, access to medicines by doctors and health care workers with a history of depression and substance abuse should be carefully monitored [19].

In course of time, there are changes in the prevalence of SU and the methods used for this. Poisoning with medicines and other substances is not the most effective way of voluntary taking one's life. However, the available access to medicines and knowledge of their toxicity and mechanisms of action remains a significant factor (with a high proportion of deaths) for doctors and health care workers to choose poisoning (drug overdose) as one of the main methods of SU.

Depression as a predictor of suicide in the profession.

SU almost always comes as the result of a lack of or inadequate treatment for depression or other MD [20]. It is assumed that manifestations of depression can be laid in early childhood. A. Surrender et al. [21] found out that the majority of men who committed or attempted SU had psychiatric problems before the age of 8 . This indicates a special propensity that persists throughout their lives. Female $\mathrm{SU}$ is not predicted to have psychopathological disorders at this age. The results provide additional evidence for the importance of early detection and treatment of psychiatric problems in male physicians. Doctors and health care providers at all stages of their careers have a (twice) higher rate of depression than the general population $(39 \%$ of doctors in the U.S.). About 400 doctors commit SU each year.

The prevalence of depression is $27 \%$ among medical students, $29 \%$ among residents and up to $60 \%$ among practitioners [22]. High professional stress and fatigue among doctors lead to sleep problems, anxiety, depression and SU [23].

According to the observations of $\mathrm{W}$. Wurm et al. [24] of the 5897 doctors surveyed, $10.3 \%$ suffered from depression: $0.9 \%$ - mild, $2.3 \%$ - moderate and $7.2 \%$ - severe. Doctors with depression also showed burnout symptoms in $87.5 \%$ of cases. The proportion of doctors suffering from depression increased depending on the degree of burnout (mild $6.8 \%$, average $-20.2 \%$, severe $-53.6 \%$ ). The 
чин и 2,27 для женщин-врачей по сравнению с общей популяцией. Как социальные, так и личностные факторы влияют на симптомы депрессии у врачей. Врачи, имеющие собственную семью, показали более низкий риск умеренной или тяжёлой депрессии, чем их неженатые коллеги. Помимо личностных факторов и семейных стрессоров, также важны факторы, связанные с работой. Профессиональный стресс инициирует депрессию. К нему относят длительный рабочий день, недосыпание, требования высокой степени профессионализма и ответственности за пациентов, ежедневные конфликты между этическими ценностями и экономическими целями, а также риск медицинских ошибок и иски о халатности. В последние десятилетия работа врачей с пациентами стала более сложной из-за возросшей нагрузки, административных обязанностей и снижения автономии.

Сниженная работоспособность, ангедония, отсутствие энергии, апатия, трудности с концентрацией внимания, возникающие негативные мысли, потеря способности к планированию и изменения восприятия истины - это проявления депрессии и возможного риска СУ. Среди работников здравоохранения медсестры являются группой, наиболее подверженной проблемам с психическим здоровьем, депрессией и риском СУ. Работая у постели больного, они имеют дело с человеческими страданиями, болью, радостью, грустью и оказывают непосредственную помощь в сложных условиях труда при отсутствии профессионального признания. Семейные конфликты, конфликты на рабочем месте, молодой возраст, ночные смены, отсутствие безопасности относятся к предикторам депрессии. Поэтому необходимо раннее выявление проблемы и улучшение микроклимата на работе во избежание печальных исходов, а также предотвращение потери качества ухода за пациентом [25].

Связь синдрома эмоционального выгорания с суицидальной активностью.

Медицинская практика, характеризующаяся большим гуманизмом и заботой о пациентах, сопровождается напряжённым характером работы, терпением, сочувствием, физическим и психологическим противостоянием стрессовым факторам, выполнением своих профессиональных обязанностей под большим административным давлением, оформлением медицинской документации. Эти аспекты влияют на личную и профессиональную жизнь врачей. Синдром эмоционального выгорания (СЭВ) определён как ПР, состоящее из эмоционального истощения, деперсонализации со склонностью к негативным и циничным мыслям по отношению к другим людям, в том числе к пациентам, и пониженного чувства личной успешности. СЭВ отличается от депрессии, поскольку относится к истощению, связанному с работой. Высокие уровни выгорания и деперсонализации, в дополнение к низкому уровню личных достижений, влияют на результативность ме- consequence of the burden of depression is the high prevalence of SU, with a total SU rate of 1.41 for male and 2.27 for female physicians compared to the general population. Both social and personal factors influence the symptoms of depression in doctors. Doctors who have a family of their own have shown a lower risk of moderate to severe depression than their unmarried counterparts. In addition to personal factors and family stressors, workrelated factors are also important. Professional stress triggers depression. These include long working hours, lack of sleep, demands for a high degree of professionalism and responsibility for patients, daily conflicts between ethical values and economic goals, and the risk of medical errors and negligence claims. In recent decades, doctors' work with patients has become more complex due to increased workload, administrative responsibilities and reduced autonomy.

Reduced working capacity, anhedonia, lack of energy, apathy, difficulties with concentration of attention, arising negative thoughts, loss of planning ability and changes in perception of truth are manifestations of depression and possible risk of SU. Among health professionals, nurses are the group most prone to mental health problems, depression and SU risk. Working at the bedside, they deal with human suffering, pain, joy, sadness and provide direct assistance in difficult working conditions in the absence of professional recognition. Family conflicts, workplace conflicts, young age, night shifts, insecurity are predictors of depression. Therefore, it is necessary to identify the problem early and improve the microclimate at work in order to avoid sad outcomes, as well as to prevent loss of quality of patient care [25].

Connection of emotional burnout syndrome with suicidal activity.

Medical practice, characterized by great humanism and care for patients, is accompanied by a strenuous nature of work, patience, compassion, physical and psychological resistance to stress factors, performing professional duties under great administrative pressure, registration of medical records. These aspects affect personal and professional lives of doctors. Burnout syndrome (BS) is defined as a MD consisting of emotional exhaustion, depersonalization with a tendency to negative and cynical thoughts towards other people, including patients, and a reduced sense of personal success. BS differs from depression because it refers to work-related exhaustion. High levels of burnout and depersonalization, in addition to a low level of personal achievement, affect the effectiveness of medical work, 
дицинской работы, взаимоотношений с пациентом и качество жизни врачей [26].

Для СЭВ характерны эмоциональное истощение, деперсонализация или чувство отрешённости по отношению к людям и работе, а также снижение чувства выполненного долга. Выгорание связано с депрессией, суицидальными идеями, алкоголизмом, наркоманией и токсикоманией, а также с непрофессиональным поведением, сокращением времени, уделённой работе и разбору врачебных ошибок [26].

СЭВ врачей достиг масштабов эпидемии и продолжает расти, хотя в других профессиях его показатели более-менее стабильны [27]. Симптомы выгорания начинаются формироваться во время обучения в медицинском ВУЗе и усиливаются во время постдипломного образования. В Северной Америке выгорание зарегистрировано у $49,6 \%$ студентов-медиков, а $11,2 \%$ сообщили о суицидальных идеях в течение года [28].

Основным фактором развития СЭВ является профиль врачебной специальности, а также условия труда и социальная составляющая, стоящие на второй и третьей позициях [29]. Обзор C. Peckham [30] показал, что выгорание является одним из основных факторов риска СУ врачей. В 2019 г. 44\% врачей сообщили о выгорании, $11 \%$ - о подавленности и блюзе, а $4 \%$ - о клинической депрессии. Наиболее «выгораемые» специальности - это неврология (53\%), хирургия (46\%), акушерство-гинекология (45\%). Среди наименее «сожжённых» - отоларингологи $(36 \%$, ) офтальмологи (34\%), патологоанатомы (28\%). Женщины-врачи признаются в выгорании чаще (50\%), чем мужчины (39\%).

В публикации Е.В. Елфимовой с соавт. [31] констатируется, что СЭВ страдают до $68 \%$ отечественных медиков, с начинающимся формированием недуга ещё у $10,5 \%$. Проявления СЭВ отмечаются у $75 \%$ невропатологов, у $57 \%$ наркологов, у 50\% стоматологов, у $47 \%$ хирургов, у $43 \%$ психиатров и у $40 \%$ терапевтов.

Состояние обусловлено наличием административных и организационных системных причин, не зависящих от конкретных врачей. Они включают в себя ограничения, связанные с оформлением электронной медицинской карты, продолжительным временем работы и значительным образовательным финансовым долгом, допущенными ошибками. Обвинения и изоляция перед лицом медицинских ошибок, неутешительные результаты лечения приводят к эмоциональной травме врача и так называемому синдрому «второй жертвы», что является как причиной, так и следствием выгорания. Кроме того, врачи страдают от интенсивной клинической нагрузки, высокого риска судебных разбирательств, хронической усталости и от нарушения циркадного ритма [32].

К факторам, вызывающим СЭВ, кроме того, относятся большие объёмы и количество административных задач (59\%), многочасовая работа и компьютеризация рабочего места (34\%), отсутствие уважения со relationships with a patient and quality of life of doctors [26].

BS is characterized by emotional exhaustion, depersonalization or a sense of detachment from people and work, as well as reduced sense of accomplishment. Burnout is associated with depression, suicidal ideation, alcoholism, drug addiction and substance abuse, as well as unprofessional behavior, reduction of time devoted to work and analysis of medical errors [26].

BS of doctors has reached epidemic proportions and continues to grow, although in other professions its indicators are more or less stable [27]. Burnout symptoms begin to form during training at a medical higher educational institution and intensify during postgraduate education. In North America, 49.6\% of medical students reported burnout, and $11.2 \%$ reported suicidal ideation dor a year [28].

The main factor in the development of BS is the profile of a medical specialty, as well as working conditions and social component, taking the second and third positions [29]. A review by C. Peckham [30] showed that burnout is a major SU risk factor for physicians. In $2019,44 \%$ of doctors reported burnout, $11 \%$ reported depression and blues, and $4 \%$ reported clinical depression. The specialties most prone to BS are neurology (53\%), surgery (46\%), obstetrics and gynecology (45\%). Among the least "burned" - otolaryngologists (36\%) ophthalmologists (34\%), pathologists (28\%). Female doctors admit to burnout more often $(50 \%)$ than men (39\%).

In the publication by E.V. Efimova et al. [31] it is stated that BS affects up to $68 \%$ of physicians in Russia, another $10.5 \%$ have started to develop BS. Manifestations of BS have been reported by $75 \%$ of neurologists, $57 \%$ of narcologists, $50 \%$ of dentists, $47 \%$ of surgeons, $43 \%$ of psychiatrists and $40 \%$ of therapists.

Such condition is due to the presence of administrative and organizational systemic causes that do not depend on specific doctors. They include limitations related to electronic medical records, long working hours and significant educational financial debt, admitted mistakes. Accusations and isolation in the face of medical errors, disappointing treatment results lead to emotional trauma of a doctor and the so-called "second victim" syndrome, which is both the cause and consequence of burnout. In addition, physicians suffer from intense clinical stress, high risk of litigation, chronic fatigue, and circadian rhythm disorders [32].

In addition, large volume and number of 
стороны администрации и коллег (30\%), недостаточная компенсация (29\%). Число «сожжённых» врачей растёт с увеличением количества часов, отработанных за неделю при недостатке сна: при нагрузке 31-40 часов в неделю $-36 \%, 71$ час и более $-57 \%$. Более 51 часа в неделю работают общие хирурги (77\%), акушерыгинекологи (60\%) и анестезиологи (54\%) [33].

Почти треть врачей сократили бы своё время работы, чтобы уменьшить СЭВ. Многие врачи довольны своей работой. Наиболее счастливыми являются офтальмологи (39\%), дерматологи (34\%) и педиатры (31\%). Отсутствие СЭВ является показателем хорошего самочувствия врача, что выражается в вовлечённости и удовлетворённости работой, чувством процветания в физическом, эмоциональном и социальном здоровье. СЭВ, напротив, приводит к ошибкам при назначении лекарств и, как следствие ведёт, к увеличению вреда для пациентов. На личном уровне выгорание нередко сопровождается депрессией и СУ среди врачей. Учитывая личные и профессиональные последствия нелеченного СЭВ, СУ является самым ужасным профессиональным императивом [33].

В литературе описываются ещё такие предикторы СЭВ, как личностные качества экстраверсии, невротизма и связанные с работой стрессовые факторы окружающей среды - тип медицинского учреждения и отношения с коллегами и начальством, а также личные проблемы, связанные с партнерскими отношениями [26].

Индивидуальные факторы, связанных с выгоранием и депрессией, включают пол, объём социальной поддержки и расстройства психического здоровья. Системные факторы, которые играют роль в СЭВ и депрессии, включают «оптимизацию» и сокращение персонала, требования оформления электронных медицинских карт, производственное давление и отсутствие личного контроля над профессиональной жизнью. Оформление получения медицинской лицензии включают вопросы, которые усиливают стигму психологических стрессов и не позволяют врачам обращаться за соответствующей помощью [33].

СЭВ вызывает такие последствия, как - снижение качества медицинской помощи, рост врачебных ошибок, неудовлетворённость пациентов и поставщиков услуг, истощение медицинской практики, усугубление нехватки и неправильного распределения врачебного персонала. «Сгоревшие» врачи не обращаются за профессиональной помощью, а пытаются справиться с депрессией и суицидальными мыслями самостоятельно [32].

Выгорание трудно распознаётся и преодолевается. Немногие врачи, которые идентифицируют себя с выгоранием, обращаются за помощью, а сотрудники с осторожностью относятся к сообщению о проблемных коллегах. Это объясняется тем, что стигма отрицания и избегания общения воспринимается как стратегии выживания из-за возможных проблем с лицензированием, прохождением конкурсного отбора и заключением administrative tasks (59\%), long hours of work and computerization of the workplace (34\%), lack of respect from the administration and colleagues (30\%), insufficient compensation $(29 \%)$ refer to the factors causing BS. The number of "burned" doctors increases with the number of hours worked per week along with a lack of sleep: at a workload of 31-40 hours per week it reaches $36 \%$, with 71 hours or more $-57 \%$. General surgeons $(77 \%)$, obstetricians-gynecologists $(60 \%)$ and anesthesiologists $(54 \%)$ work more than 51 hours a week [33].

Almost one third of doctors would cut their work time to reduce BS. Many doctors are satisfied with their work. The happiest are ophthalmologists (39\%), dermatologists (34\%) and pediatricians $(31 \%)$. The absence of $\mathrm{BS}$ is an indicator of a doctor's well-being, which is expressed in engagement and job satisfaction, a sense of prosperity in physical, emotional and social health. BS, in contrast, leads to errors in prescribing medicines and, as a consequence, leads to increased harm to patients. Taking personal and professional consequences of untreated BS into account, SU is the most terrible professional imperative [33].

The literature describes other predictors of BS, such as personal qualities of extroversion, neuroticism and work-related environmental stress factors - the type of medical institution and relationships with colleagues and superiors, as well as personal problems associated with partnership [26].

Individual factors associated with burnout and depression include gender, amount of social support, and mental health disorders. Systemic factors that matter in BS and depression include "optimization" and reduction of staff, electronic health record requirements, work pressure, and lack of personal control over professional life. Obtaining a medical license includes issues that increase the stigma of psychological stress and do not allow doctors to seek appropriate help [33].

BS results in the reduction of the quality of medical care, increase of medical errors, dissatisfaction of patients and service providers, depletion of medical practice, growing shortage and inappropriate distribution of medical personnel. "Burned" doctors do not seek professional help, but try to cope with depression and suicidal thoughts on their own [32].

Burnout is difficult to recognize and overcome. Few doctors with BS call for help, and the staff treat their troubled colleagues with reserve. This is because the stigma of denial and avoidance of communication is perceived as a survival strategy due to possible 
(продлением) последующих контрактов. Стратегию улучшения здоровья врачей рекомендуется нацелить на организационные моменты, а также на отдельных врачей. Вмешательства, направленные на организацию рабочего процесса, например, увеличение автономии и изменения в графике работы, связаны с умеренным, но существенным снижением выгорания врача. Эти мероприятия более эффективны, чем личностные, ориентированные на врача, такие как внимательность, повышение квалификации, управление стрессом, хотя комбинированные подходы, вероятно, являются наиболее успешными [34].

Между тем, в систематическом обзоре L.S. Rotenstein и соавт. (182 исследования с участием 109628 человек в 45 странах, опубликованных с 1991 по 2018 гг.) были отмечены существенные различия в оценках распространённости выгорания (от 0 до $86,2 \%$ ), деперсонализации (от 0 до 89,9\%) и показателях низких достижений врача (от 0 до 87,1\%). Констатируются заметные различия в определении СЭВ и методах его оценки. Эти результаты пока исключают окончательные выводы о распространённости СЭВ и подчеркивают важность достижения консенсуса по определению СЭВ, стандартизации инструментов его измерения и оценки воздействия хронического профессионального стресса на врачей [35].

Низкая личная удовлетворённость и самоубийства.

Принятие решения о совершении добровольного ухода из жизни на всех этапах суицидальной динамики не носит спонтанного характера. Реализация суицидальных замыслов возможна при актуализации какоголибо внешнего события / фактора, выделенного самим суицидентом, и представляющее собой индивидуально значимое психологическое образование, названное П.Б. Зотовым «внешним ключом». «Внешний ключ» обычно осознаваем суицидентом, и является объектом психоррекционной работы [36].

В зарубежной литературе используется термин «сорванная принадлежность» (thwarted belongingness. Указанный фактор запускает программу реализации суицидальных действий. «Сорванная принадлежность» - это психологически болезненное состояние психики, которое возникает, когда человек отчуждён от социальной среды, референтной группы, например, врачебного «сословия». В результате этого фундаментальная потребность в «необходимости принадлежать» является неудовлетворённой. Предполагается, что различные показатели социальной изоляции - жизнь в одиночестве, низкая социальная поддержка и общение (профессиональное, бытовое) - связаны с депрессией и СУ на протяжении всей жизни, и являются признаками того, что потребность в принадлежности была «сорвана» и перспективы самореализации отсутствуют. Одиночество ассоциируется с личностными расстройствами и другими ПР, СУ, ухудшением когнитивных функ- problems with licensing, competitive selection and conclusion (extension) of subsequent contracts. The strategy for improving the health of doctors would suggest to focus on organizational issues, as well as on individual doctors. Interventions aimed at organizing the work process, such as increased autonomy and changes in the work schedule, are associated with a moderate but significant reduction of doctors' burnout. These measures are more effective than personal, physician-focused interventions such as mindfulness, skill development, and stress management, although combined approaches are probably the most successful [34].

Meanwhile, in a systematic review by L.S. Rotenstein et al. (182 studies involving 109.628 people in 45 countries published from 1991 to 2018) there were significant differences in estimates of burnout prevalence (0 to $86.2 \%$ ), depersonalization ( 0 to $89.9 \%$ ), and rates of low physician achievement (0 to $87.1 \%)$. There are marked differences in the definition of BS and methods of its evaluation. These results so far exclude definitive conclusions about the prevalence of BS and emphasize the importance of reaching consensus on the definition of BS, standardization of tools for its measurement and evaluation of the impact of chronic occupational stress on physicians [35].

Low personal satisfaction and suicide.

The decision to voluntarily take one's life at all stages of suicide is not spontaneous. The implementation of suicidal intentions is possible by realization of any external event, which P. B. Zotov named "external key" [36], representing a personal and especially significant factor of unmet need for the individual. In foreign literature, the term "thwarted belongingness" is used. The specified factor starts the program of realization of suicidal actions.

"Thwarted belongingness" is a psychologically painful state of mind that occurs when a person is alienated from a social environment, a reference group, for example, a medical "society". As a result, the fundamental need for the "membership" is unmet. It is assumed that various indicators of social isolation - living alone, low social support and communication (professional, domestic) - are associated with depression and SU throughout life, and are the signs that the need for belonging has been "thwarted" and there are no prospects for self-realization. Loneliness is associated with personality disorders and other $\mathrm{MD}, \mathrm{SU}$, cognitive impairment, increased risk of Alzheimer's disease, decreased executive control, and enhanced symptoms of depression 
ций, повышенным риском развития болезни Альцгеймера, снижением исполнительного контроля и усиливает симптомы депрессии [37].

Медицинская практика, изменившаяся за последние годы, привела к неудовлетворённости врачей своей работой. Работать приходится в больших коллективах с оценкой, касающейся выбора методов лечения. Доказательная медицина привела к снижению автономии и самостоятельности. Экономические вопросы, касающиеся стоимости лечения, влияют на восприятие удовлетворённости работой. В модель стрессового опыта врача факторным анализом, проведённым M. Pedrazza и соавт. [38] внесены личные и судебные издержки, снижение общественного имиджа и престижа, неуверенность в профессии, ответственность перед безнадежно больными пациентами, напряжённые межличностные отношения с коллегами и администрирование.

Развитие юридической системы при оказании врачебной помощи существенно изменило общие условия медицинской практики. Связанный с судебными разбирательствами стресс провоцирует депрессию и суицидальное поведение. Иски о халатности тесно связаны с СЭВ, депрессией и мыслями о СУ, особенно среди хирургов. В многопараметрическом моделировании депрессия и выгорание были независимо связаны с недавним иском о халатности. Часы работы, ночные вызова и специальность также связаны с недавними исками о злоупотреблениях. Хирурги, которые столкнулись с иском о халатности, сообщали о меньшей удовлетворённости карьерой и реже рекомендовали хирургическую или медицинскую карьеру своим детям [39].

Ангедония и суицидальное поведение.

Взаимосвязь между различными видами суицидальной активности (мыслями, намерениями, попытками) и ангедонией (снижением или утратой способности получать удовольствие) исследована в большой выборке врачей с использованием межличностной психологической теории CУ. G. Loas и соавт. (2018) подтвердили две гипотезы: во-первых, что существует выраженная связь между ангедонией и СУ, и, во-вторых, что ангедония может опосредовать отношения между суицидными идеями или попытками СУ и «сорванной принадлежностью» [40].

В перекрёстном исследовании 557 врачей заполнили анкеты для оценки риска СУ, депрессии, используя сокращённую версию шкалы депрессии Бека, а также демографические и связанные с работой опросники. Обнаружены значительные связи между ангедонией, суицидальными идеями и попытками СУ, даже когда были приняты во внимание значительные переменные и ковариаты, в частности, депрессивные симптомы. Анализ показал, что ангедония опосредовала отношения между суицидальными идеями (в течение жизни или недавними) и воспринимаемым бременем «сорванной принадлежности». Для попыток СУ также была найдена взаимосвязь между ангедонией и «сорванной
[37].

Medical practice, which has changed in recent years, has led to dissatisfaction of doctors with their work. It is necessary to work in large teams with the assessment concerning the choice of treatment methods. Evidencebased medicine has reduced autonomy and independence. Economic issues related to the cost of treatment affect perception of job satisfaction. By means of factor analysis conducted by M. Pedrazza et al. [38] personal and legal costs, loss of public image and prestige, uncertainty in the profession, responsibility to terminally ill patients, strained interpersonal relationships with colleagues and administration are included into the model of physician's stress experience.

Development of the legal system in the provision of medical care has significantly changed the general conditions of medical practice. Litigation-related stress triggers depression and suicidal behavior. Malpractice suits are closely linked to BS, depression and SU thoughts, especially among surgeons. In multiparameter modeling, depression and burnout were independently linked to a recent malpractice suit. Hours of work, night calls and specialty are also linked to recent negligence lawsuits. Surgeons who faced a malpractice suit reported less career satisfaction and were less likely to recommend a surgical or medical career to their children [39].

Anhedonia and suicidal behavior.

The relationship between different types of suicidal activity (thoughts, intentions, attempts) and anhedonia (decrease or loss of the ability to enjoy) was studied in a large sample of physicians using the interpersonal psychological theory of SU. G. Loas et al. (2018) confirmed two hypotheses: first, that there is an apparent relationship between anhedonia and SU, and second, that anhedonia may mediate the relationship between suicidal ideas or SU attempts and "thwarted belongingness" [40].

In the cross-sectional study, 557 physicians completed questionnaires to assess the risk of SU, depression using an abbreviated version of the Beck depression scale, and also demographic and work-related questionnaires. Significant links have been found between anhedonia, suicidal ideation and SU attempts, even when significant variables and covariates, particularly depressive symptoms, have been taken into account. The analysis showed that anhedonia mediated the relationship between suicidal ideas (over a lifetime or recent) and the perceived burden of "thwarted belongingness". For SU attempts, a relationship between anhedonia and "thwarted belonging- 
принадлежностью». Когда были приняты во внимание различные компоненты ангедонии, неудовлетворённость имела существенную ассоциацию с суицидальным представлением, тогда как запрет работы имел отношение к попыткам СУ. Ангедония и её компонент неудовлетворённости являются фактором риска суицидальных мыслей и опосредуют связь между ними и «сорванной принадлежностью» врачей. Неудовлетворённость, особенно на рабочем месте, рассматривается как сильный предиктор суицидальных мыслей врачей и работников здравоохранения [40].

Фактически, врачи многих стран страдают от бремени повышенного уровня СУ. Исследование M. Wall и соавт. [41] показало наличие суицидальных идей в течение года у $18 \%$ (из 149) итальянских и у $12 \%$ (из 272) шведских хирургов. Самая сильная связь с мыслями о СУ в обеих странах вызвана унизительным опытом и преследованием со стороны администрации учреждения (старшего врача). Болезнь, перенесённая «на ногах», истощение и разобщённость коллектива связаны с возникновением идеи СУ среди итальянских хирургов. Для их шведских коллег преследование и унижение на работе связаны с недавними суицидальными намерениями. Регулярные обсуждения конфликтных и проблемных ситуаций на работе способствуют редукции суицидальных мыслей (тенденций).

Профилактика суицидального поведения .

Профилактика СУ лежит в основе оперативной программы ВОЗ, цель которой - снизить показатели СУ на $10 \%$ к 2020 г. Важность выявления риска в профилактике СУ очевидна из того факта, что $91 \%$ из тех, кто погибает в результате СУ, в какой-то момент общались с врачами и/или медработниками в течение года до смерти, и что $66 \%$ участвуют в сетях психического здоровья, в основном в амбулаторных центрах [42].

Некоторые проблемы делают профилактику СУ у врачей весьма сложной. Врачи, традиционно не хотят обращаться за помощью. Когда сталкиваются с проблемами, пытаются решить их путём самолечения. В свете повышенного уровня СУ это может указывать на то, что врачи редко просят о помощи, и действуют исходя из своих суицидальных мыслей. Таким образом, есть веская причина для особой настороженности при обнаружении или подозрении, что кто-то из коллег борется с суицидом.

Для снижения риска СУ среди врачей Норвегии реализуются следующие стратегии помощи. Доступны два варианта, когда врачи, подверженные стрессу, обращаются за советом и помощью. Во всех округах врачи имеют доступ к специально назначенным коллегам по поддержке. Кроме того, врачи обращаются за помощью в Ресурсный центр, финансируемый Норвежской медицинской ассоциацией. У большинства врачей есть собственный врач общей практики, а в некоторых округах действует схема «врач для врача» для лечения коллег. Во-вторых, ответственностью коллег. Важно ness" was also found. When various components of anhedonia were taken into account, dissatisfaction had a significant association with suicidal ideation, whereas the prohibition of work had to do with SU attempts. Anhedonia and its dissatisfaction component are a risk factor for suicidal thoughts and mediate the link between them and doctors' "thwarted belongingness". Dissatisfaction, especially in the workplace, is seen as a strong predictor of suicidal thoughts among doctors and health care workers [40].

In fact, doctors in many countries suffer from the burden of enhanced SU level. The study of M. Wall et al. [41] showed suicidal ideation during the year in $18 \%$ (out of 149) Italian and $12 \%$ (out of 272) Swedish surgeons. The strongest association with $\mathrm{SU}$ thoughts in both countries is due to humiliating experiences and harassment by the administration of the medical institution (senior physician). Working ill, without proper treatment, exhaustion and disunity of the team are connected with the emergence of the idea of SU among Italian surgeons. For their Swedish colleagues, harassment and humiliation at work are linked to recent suicidal intentions. Regular discussions of conflict and problem situations at work contribute to the reduction of suicidal thoughts (tendencies).

Prevention of suicidal behavior among doctors and health care workers.

Prevention of SU is at the heart of World Health Organization operative programme, which aims at reducing SU by $10 \%$ by 2020 . The importance of risk identification in $\mathrm{SU}$ prevention is evident from the fact that $91 \%$ of those who die in the result of SU have at some point communicated with doctors and/or health care providers in the year prior to death, and that $66 \%$ participate in mental health networks, mostly in outpatient centers [42].

Some problems make the prevention of SU in doctors very difficult. Doctors traditionally do not want to ask for help. When they face problems, they try to solve them by selfmedication. In the light of increased SU levels, this may indicate that doctors rarely seek help, and act on their suicidal thoughts. Thus, there is a good reason to be particularly careful on discovering or suspecting that a colleague is struggling with suicide.

To reduce the risk of SU among Norwegian doctors, the following helping strategies are implemented. There are two options available when stressed doctors seek advice and help. In all districts, doctors have access to designated supporting colleagues. Doctors also turn for help to a Resource centre funded by the Norwegian Medical Association. Most 
знать лиц, у которых есть проблемы с психическим здоровьем, включая злоупотребление психоактивными веществами, и вносить свой вклад в обеспечение того, чтобы они проходили лечение и были защищены от выполнения обязанностей, которые могут усугубить ситуацию. Важно определить тех, кто борется с суицидом на ранней стадии, чтобы убедиться, что они получают помощь, прежде чем их проблемы приобретут такие масштабы, что возникает завершённый суицид [43].

При высоком уровне депрессии, выгорания, меж- и внутриличностных проблем и СУ, лечение получают лишь меньшинство врачей и медработников. Опасения относительно конфиденциальности, потенциальных последствий для карьеры, а также затрат и временных ограничений упоминаются в качестве основных барьеров. Важной стратегией профилактики СУ врачей и медработников являются раннее выявление и оптимальное лечение ПР, особенно депрессивных состояний, СЭВ, оптимизация межличностных отношений на работе, и признание важности поддержки семьи, начиная со студенчества [16].

Типичные способы лечения депрессии варьируют и включают применение антидепрессантных препаратов первой линии - ингибиторов моноаминоксидазы; трициклических антидепрессантов, селективных ингибиторов обратного захвата серотонина. Отсутствие результативности препарата первой линии требует назначения второго (другого) средства. Лекарства имеют разную степень эффективности, а побочные эффекты могут варьировать от сексуальной дисфункции до тревоги, бессонницы и СУ [44].

Кокрановский обзор показывает, что психотерапия, добавленная к лечению антидепрессантами пациентов с депрессией, является приемлемой для смягчения её симптомов и становления ремиссии [45]. Е.Б. Любовым, П.Б. Зотовым [46] разработан и внедрён персонифицированный алгоритм диагностики и профилактики суицидального поведения, применимый и к работникам здравоохранения.

Предоставлены доказательства, что различные нефармакологические вмешательства могут улучшать симптомы депрессии с эффективностью, сравнимой с антидепрессантами. Например, когнитивно - поведенческая терапия эффективна при лёгкой, умеренной и тяжелой депрессии [46]. Светотерапия, комплексное применение метафорической суггестии и акупунктуры, которые обладают свойством малых антидепрессантов и обеспечивают регуляцию сна, купирование тревоги и суицидальных наклонностей.

Предотвращение выгорания обеспечивается претворением организационных мероприятий, включая адаптацию цифровых стратегий здравоохранения. Личная неудовлетворённость преодолевается мотивацией и повышением уровня притязаний, налаживанием межличностных отношений и общения. Психиатру (психотерапевту) необходимо помочь своему врачу- doctors have their own GP, and some districts have a doctor-for-doctor scheme to treat colleagues. Second, the responsibility of colleagues. It is important to know the individuals who have mental health problems, including substance abuse, in order to ensure that they receive treatment and are protected from situations that can exacerbate the situation. It is important to identify those struggling with suicide at an early stage to make sure they get help before their problems take on such proportions that a completed suicide occurs [43].

At a high level of depression, burnout, inter- and intrapersonal problems and SU, only a minority of doctors and health care workers receive treatment. Concerns about privacy, potential career implications, cost and time constraints are cited as the major barriers. Early detection and optimal treatment of MD, especially depressive disorders, BS, optimization of interpersonal relations at work, and recognition of the importance of family support, starting from studentship are an important strategy for the prevention of SU in doctors and health care workers [16].

Typical methods of treatment for depression vary and include the use of first-line antidepressant drugs - monoamine oxidase inhibitors; tricyclic antidepressants, selective serotonin reuptake inhibitors. The lack of effectiveness of the first-line drug requires the prescription of the second (other) medication. Drugs have different degrees of effectiveness, and side effects can range from sexual dysfunction to anxiety, insomnia and SU [44].

The Cochrane review shows that psychotherapy added to antidepressant treatment of patients with depression is appropriate for mitigating its symptoms and achieving remission [45]. E.B. Lyubov, P.B. Zotov [46] developed and implemented a personalized algorithm for the diagnosis and prevention of suicidal behavior, applicable to health care workers.

Evidence has been provided that various non-pharmacological interventions can improve symptoms of depression with efficacy comparable to antidepressants. For example, cognitive behavioral therapy is effective in mild, moderate, and severe depression [46]. Light therapy, complex application of metaphorical suggestion and acupuncture, which have the property of small antidepressants and provide regulation of sleep, relief of anxiety and suicidal tendencies.

Burnout prevention is ensured by the implementation of organizational measures, including the adaptation of digital strategies of public health service. Personal dissatisfaction is overcome by motivation and increasing 
пациенту определиться, следует ли ему продолжать врачебную практику [49].

S. Pospos и соавт. [49] напоминают, что существующие Веб- и мобильные приложения смягчают стресс, истощение, депрессию и купируют суицидальные мысли (тенденции). Определены категории онлайн программ с высокой эффективностью - это когнитивно поведенческая и дыхательная терапия, медитация, методы повышения внимательности и расслабления, видеоигры и приложения для предотвращения СУ.

Самоубийства среди врачей и медработников в России.

Статистика СУ среди представителей врачебного и медицинского сообщества в нашей стране на сегодняшний день отсутствует. Однако с учётом обсуждаемого в обзоре материала есть все основания говорить о чрезвычайной важности этой проблемы. В средствах массовой информации, включая электронные ресурсы и Интернет, нередко упоминаются случаи СУ среди врачей и медработников. Главные причины СУ - это возбуждение уголовных дел против врачей за допущенные врачебные ошибки (халатность) при выполнении своих профессиональных обязанностей, проявления коррупции (получение взяток), наличие неизлечимых болезней; среди среднего медперсонала - семейные (личные) и межличностные проблемы. В России есть все основания предполагать схожие с зарубежными странами факторы, способствующие суицидальной активности среди врачей и медработников. Более того, в условиях продолжающихся реформ (оптимизации) здравоохранения продолжают ухудшаться условия работы: резко возрастает нагрузка при достаточно низкой зарплате и повышенной ответственности за результаты своего труда. Все это ускоряет развитие СЭВ, повышает уровень стресса, снижает показатели удовлетворённости от работы, способствует формированию депрессивных состояний [50] и повышению суицидальной активности [19]. Существенным факторам совершения СУ можно рассматривать злоупотребление алкоголем, другими психоактивными веществами и снотворными препаратами. Е.А. Бодагова и Н.В. Говорин указывают, что у 10,6\% врачей имелась наркологическая патология, высокая доля невротических (стрессовых) расстройств; СЭВ был сформирован у 67,6\% [51]. Наши наблюдения свидетельствуют о том, что распространённость алкогольной зависимости среди врачей сопоставима с показателями официальной статистики среди населения региона [52]. Можно прогнозировать достаточно высокую суицидальную активность среди врачей и медперсонала по сравнению с их зарубежными коллегами. Высокие показатели СУ среди населения России, возможно, снижают остроту СУ среди врачей и медработников (ниже, чем в населении). Кроме того, злоупотребление кодами «Повреждение с неопределенными намерениями» (по МКБ-10) приводит к невозможности объективно оценить структуру смертно- ambitions, establishing interpersonal relationships and communication. A psychiatrist (psychotherapist) should help his doctor-patient to decide whether he should continue medical practice [49].

S. Pospos et al. [49] remind that existing web- and mobile applications mitigate stress, exhaustion, depression and stop suicidal thoughts (tendencies). The categories of online programs with high efficiency are designated and represent cognitive behavioral and respiratory therapy, meditation, mindfulness and relaxation techniques, video games and applications to prevent SU.

Suicide among doctors and health care workers in Russia.

SU statistics for representatives of the medical community in our country today is missing. However, in view of the material discussed in the review, there is every reason to say that this problem is extremely important. Cases of SU among doctors and health care workers are often mentioned in the media, including electronic resources and the Internet. The main reasons for SU is the initiation of criminal proceedings against doctors for medical errors (negligence) in performing their professional duties, manifestations of corruption (bribery), presence of incurable diseases; among nurses - family (personal) and interpersonal problems. In Russia, there is every reason to assume similar factors as in foreign countries that contribute to suicidal activity among doctors and health care workers. Moreover, in the context of ongoing reforms (optimization) of health care, working conditions continue to deteriorate: the load increases sharply with a sufficiently low salary and increased responsibility for the results of their work. All this accelerates the development of BS, increases stress levels, reduces job satisfaction, contributes to the formation of depressive states [50] and increases suicidal activity [19]. Abuse of alcohol, other psychoactive substances and sleeping pills can be considered a significant factor in the commission of SU. E.A. Bodagova, N.V. Govorin indicate that $10.6 \%$ of doctors had narcological pathology, a high proportion of neurotic (stress) disorders; BS was reported in $67.6 \%$ cases [51].

Our observations indicate that the prevalence of alcohol abuse among doctors is comparable to the official statistics among the population of the region [52]. It is possible to predict rather high suicidal activity among doctors and medical staff in comparison to their foreign colleagues. High rates of SU among the Russian population may mitigate downward SU among doctors and health care workers (lower than in the population). In 
сти от внешних причин, существенно затрудняет анализ СУ в профессиональных группах и получение объективных оценок [53]. Отсутствие исследований по указанной проблеме делает пока невозможным разработку дифференцированных профилактических мероприятий в медицинских организациях нашей страны.

Заключение. Суицидальное поведение весьма распространённое явление среди врачей и медработников за рубежом, превосходящее в 1,5-4 раза показатели СУ среди населения этих стран. Однозначно просматривается комплекс связанных с профессией факторов, которые способствуют суицидальной активности работников системы здравоохранения. Большая распространённость различных и повторяющихся стрессов участвует в развитии депрессивных состояний, СЭВ, сопровождается неудовлетворённостью работой и ангедонией у врачей и медработников. Их профессиональные знания о сильнодействующих лекарственных средствах и довольно свободный доступ к ним является одной из возможностей к реализации, возникающих и имеющихся суицидальных тенденций.

Суицидальное поведение является предотвратимой причиной смерти врачей и медработников. Своевременное обнаружение, психологическое и медикаментозное пособие могут способствовать профилактике суицидального поведения, обусловленного депрессией, выгоранием, неудовлетворённостью, особенно на работе. Настороженность коллег, социализация, поведенческое, персонализированное суггестивное рефлексотерапевтическое воздействие позволяют предотвратить реализацию суицидальных намерений персонала медицинских учреждений. Ограничение доступа к смертельным средствам является важной стратегией в предотвращении СУ.

В России обсуждаемая в обзоре проблема пока мало изучена, не известна распространённость СУ среди врачей и медработников, с учётом особенностей в медицинских организациях и специальностей, хотя факторы, способствующие преждевременному и добровольному уходу их из жизни, совпадают с данными зарубежной литературы. Поэтому есть все основания говорить о чрезвычайной актуальности суицидального поведения и его профилактике среди представителей медицинских профессий в нашей стране. addition, the abuse of the codes "Damage with uncertain intentions" (according to ICD-10) leads to the inability to objectively assess the structure of mortality from external causes, significantly complicates the analysis of SU in occupational groups and obtaining objective estimates [53]. The lack of research on this problem makes it impossible to develop differentiated preventive measures in medical organizations of our country.

Conclusion. Suicidal behavior is very common among doctors and health care workers abroad, exceeding 1.5-4 times the SU rates for the population of these countries. A complex of factors related to the profession that contribute to the suicidal activity of health care workers is clearly visible. The high prevalence of various and repeated stresses is involved in the development of depressive states, BS, accompanied by dissatisfaction with work and anhedonia in doctors and health care workers. Their professional knowledge of potent drugs and fairly easy access to them is one of the opportunities to implement emerging and existing suicidal tendencies.

Suicidal behavior is a preventable cause of death for doctors and health care workers. Timely detection, psychological and medical benefits can contribute to the prevention of suicidal behavior due to depression, burnout, dissatisfaction, especially at work. Wariness of colleagues, socialization, behavioral personalized suggestive reflexotherapeutic manipulation prevent the implementation of suicidal intentions of the personnel of medical institutions. Restriction of the access to lethal drugs is an important strategy in SU prevention.

In Russia, the problem discussed in the review is still poorly studied, the prevalence of SU among doctors and health workers is not known, taking into account the peculiarities in medical organizations and specialties, although the factors contributing to their premature and voluntary retirement from life coincide with the data of foreign literature. Therefore, there is every reason to talk about the extreme relevance of suicidal behavior and its prevention among health professionals in our country.
Литература / References:

1. Любов Е.Б., Морев М.В., Фалалеева О.И. Экономическое бремя суицидов в Российской Федерации. Суицидология. 2012; 3 (3): 3-10. [Lyubov E.B., Morev M.V., Falaleeva O.I. The economic suicide burden in Russian Federation. Suicidology. 2012; 3(3): 3-10.] (In Russ)

2. Aladağ A.E., Muderrisoglu S., Akbas N.B., et al. Detecting suicidal ideation on forums: proof-of-concept study. J. Med. Internet Res. 2018; 20 (6): e215. doi: 10.2196/jmir.9840.

3. Turecki G., Brent D.A. Suicide and suicidal behaviour. Lancet. 2016; 387 (10024): 1227-1239. doi: 10.1016/S0140-6736(15)00234-2.

4. Agerbo E., Gunnell D., Bonde J.P., Mortensen P.B., Nordentoft M. Suicide and occupation: the impact of socio-economic, demographic and psychiatric differences. Psychol. Med. 2007; 37 (8): 1131-1140. doi: 10.1017/S0033291707000487.
5. Milner A.J., Maheen H., Bismark M.M., Spittal M.J. Suicide by health professionals: a retrospective mortality study in Australia, 2001-2012. Med. J. Aust. 2016; 205 (6): 260-265. doi: 10.5694/mja15.01044.

6. Schernhammer E.S., Colditz G.A. Suicide rates among physicians: a quantitative and gender assessment (meta-analysis). Am. J. Psychiatry. 2004; 161 (12): 2295-2302. doi: 10.1176/appi.ajp.161.12.2295.

7. Frank E., Dingle A.D. Self-reported depression and suicide attempts among U.S. women physicians. Am. J. Psychiatry. 1999; 156 (12): 1887-1894. doi: 10.1176/ajp.156.12.1887.

8. Albuquerque J., Tulk S. Physician suicide. CMAJ. 2019; 191 (18): 505. doi: 10.1503/cmaj.181687.

9. Revicki D.A., May H.J. Physician suicide in North Carolina. South Med. J. 1985; Oct. 78 (10): 1205-1207.

10. Grinshteyn E., Hemenway D. Violent Death Rates: The US Compared with Other High-income OECD Countries, 2010. Am. J. Med. 2016; Mar. 129 (3): 266-273. doi: 10.1016/j.amjmed.2015.10.025. 
11. Krug E.G., Powell K.E., Dahlberg L.L. Firearm-related deaths in the United States and 35 other high- and upper-middleincome countries. Int. J. Epidemiol. 1998; Apr. 27 (2): 214-221.

12. Gold K.J., Sen A., Schwenk T.L. Details on suicide among US physicians: data from the National Violent Death Reporting System. Gen. Hosp. Psychiatry. 2013; 35 (1): 45-49.

13. Collier R. Physician suicide too often «brushed under the rug». CMAJ. 2017; 189 (39): 1240-1241. doi: 10.1503/cmaj.1095498.

14. Lagro-Janssen A.L., Luijks H.D. Suicide in female and male physicians. Ned. Tijdschr. Geneeskd. 2008; 4.152 (40): 2177-2181.

15. Grellner W., Kukuk M.,Glenewinkel F. About suicide methods of physicians, medical personnel and related professions. Arch. Kriminol. 1998; Mar-Apr. 201 (3-4): 65-72.

16. Visanuyothin T., Srivaranundh K., Siriwej P., et al. Risk factors for suicide among Thai physicians. J. Med. Assoc Thai. 2004; 87 (Suppl 4): 14-18

17. Shang T.F., Chen P.C., Wang J.D. Mortality of doctors in Taiwan. Occup. Med. (Lond). 2011; Jan. 61 (1): 29-32. doi 10.1093/occmed/kqq159.

18. Skegg K., Firth H., Gray A., Cox B. Suicide by occupation: does access to means increase the risk? Aust. NZJ. Psychiatry. 2010 May. 44 (5): 429-434. doi: 10.3109/00048670903487191.

19. Austin A.E., van den Heuvel C., Byard R.W. Physician suicide. J. Forensic Sci. 2013; 58 (s1): 91-93.

20. Gagné P., Moamai J., Bourget D. Psychopathology and Suicide among Quebec physicians: a nested case control study. Depress. Res. Treat. 2011; 2011: 936327. doi: 10.1155/2011/936327.

21. Sourander A., Klomek A.B., Niemelä S., et al. Childhood predictors of completed and severe suicide attempts: findings from the Finnish 1981 birth cohort study. Arch. Gen. Psychiatry. 2009; 66 (4): 398 406. doi: 10.1001/archgenpsychiatry.2009.21.

22. Bailey E., Robinson J., McGorry P. Depression and suicide among medical practitioners in Australia. Intern. Med. J. 2018; 48 (3): 254-258. doi: 10.1111/imj.13717.

23. Huang C.L., Weng S.F., Wang J.J., et al. Risks of Treated Insomnia, Anxiety, and Depression in Health Care-Seeking Physicians: A Nationwide Population-Based Study. Medicine (Baltimore). 2015; 94 (35): e1323 doi: 10.1097/MD.0000000000001323.

24. Wurm W., Vogel K., Holl A., Ebner C., Bayer D., Mörkl S., Szilagyi I.S., Hotter E., Kapfhammer H.P., Hofmann P. Depression-burnout overlap in physicians. PLoS One. 2016; 11 (3): e0149913. doi: 10.1371/journal.pone.0149913.

25. Silva Ddos S., Tavares N.V., Alexandre A.R., et al. Depression and suicide risk among nursing professionals: an integrative review. Rev. Esc. Enferm. USP. 2015; 49 (6): 1027-1036.

26. Iorga M., Socolov V., Muraru D., Dirtu C., Soponaru C., Ilea C., Socolov D.G. Factors influencing burnout syndrome in obstetrics and gynecology physicians. Biomed Res. Int. 2017; 2017: 9318534. doi: $10.1155 / 2017 / 9318534$.

27. Rothenberger D.A. Physician burnout and well-being: a systematic review and framework for action. Dis. Colon. Rectum. 2017; 60 (6): 567-576. doi: 10.1097/DCR.0000000000000844

28. Dyrbye L.N., Thomas M.R., Massie F.S., Power D.V., Eacker A., Harper W., Durning S., Moutier C., Szydlo D.W., Novotny P.J., Sloan J.A., Shanafelt T.D. Burnout and suicidal ideation among U.S. medical students. Ann. Intern. Med. 2008; 149 (5): 334-341. doi: 10.7326/0003-4819-149-5-200809020-00008

29. Малыгин В.Л., Искандирова А.Б., Пахтусова Е.Е., и др. Социальные и профессиональные факторы риска формирования эмоционального выгорания у врачей психиатров и наркологов. Прикладнье информачионные аспекты медииины. 2008; (11) 1: 71-75. [Malygin V.L., Iskandirova A.B., Pakhtusova E.E., et al. Social and professional risk factors of formation of emotional burning out of doctors of psychiatris and addictors. Applied informational aspects of medicine. 2008; (11) 1: 71-75. (In Russ)

30. Peckham C. Medscape national physician burnout \& depression report 2019. Medscape. 2019. [Accessed February 23, 2019] Available at: https://www.medscape.com/slideshow/2019 lifestyle-burnout-depression-6011056\#2.

31. Елфимова Е.В., Елфимов М.А., Березкин А.С. Как предотвратить синдром эмоционального выгорания у медицинских работников? Экспериментальная и клиническая гастроэнтерология. 2016; 5 (129): 83-87. Elfimova E.V., Elfimov M.A., Berezkin A.S. How to prevent emotional burnout syndrome in health professionals? Experimental and clinical gastroenterology. 2016; 5 (129): 83-87. (In Russ)

32. Stehman C.R., Testo Z., Gershaw R.S., Kellogg A.R. Burnout, drop out, suicide: physician loss in emergency medicine, Part I West J. Emerg. Med. 2019; 20 (3): 485-494. doi: 10.5811/westjem.2019.4.40970.
33. Kuhn C.M., Flanagan E.M. Self-care as a professional imperative: physician burnout, depression, and suicide. Can. J. Anaesth. 2017; 64 (2): 158-168. doi: 10.1007/s12630-016-0781-0.

34. Ruzycki S.M., Lemaire J.B. Physician burnout. CMAJ. 2018; 190 (2): 53. doi: 10.1503/cmaj.170827.

35. Rotenstein L.S., Torre M., Ramos M.A., et al. Prevalence of Burnout Among Physicians: A Systematic Review. JAMA. 2018; Sep. 18. 320 (11): 1131-1150. doi: 10.1001/jama.2018.12777.

36. Зотов П.Б. Суицидальное поведение: роль «внешнего ключа», как элемента суицидальной динамики и объекта психотерапии. Российский медико-биологический вестник им. Акад. И.П. Павлова. 2015; 23 (4): 133-137. [Zotov P.B. Suicidal behavior: the role of the "foreign key" as an element of suicidal dynamics and the object of psychotherapy. Russian Medical and Biological Bulletin named after Acad. I.P. Pavlova.. 2015; 23 (4): 133-137.] (In Russ)

37. Hawkley L.C., Cacioppo J.T. Loneliness matters: a theoretical and empirical review of consequences and mechanisms. Ann. Behav. Med. 2010; 40 (2): 218-227. doi: 10.1007/s12160-010-9210-8.

38. Pedrazza M., Berlanda S., Trifiletti E., Bressan F. Exploring physicians' dissatisfaction and work-related stress: development of the PhyDis scale. Front. Psychol. 2016; 7: 1238. doi: 10.3389/fpsyg.2016.01238

39. Balch C.M., Oreskovich M.R., Dyrbye L.N., et al. Personal consequences of malpractice lawsuits on American surgeons. J. Am. Coll. Surg. 2011; 213(5): 657-667. doi: 10.1016/j.jamcollsurg.2011.08.005.

40. Loas G., Lefebvre G., Rotsaert M., Englert Y. Relationships between anhedonia, suicidal ideation and suicide attempts in a large sample of physicians. PLoS One. 2018; 13 (3): e0193619. doi: 10.1371/journal.pone.0193619.

41. Wall M., Schenck-Gustafsson K., Minucci D., et al. Suicidal ideation among surgeons in Italy and Sweden - a cross-sectional study. BMC Psychol. 2014; 2 (1): 53. doi: 10.1186/s40359-014-0053-0.

42. Muñoz-Sánchez J.L., Sánchez-Gómez M.C., Martín-Cilleros M.V., et al. Addressing suicide risk according to different healthcare professionals in Spain: a qualitative study. Int. J. Environ Res. Public Health. 2018; 15 (10): 2117. doi: 10.3390/ijerph15102117.

43. Hem E. Suicide among doctors. Tidsskr. Nor. Laegeforen. 2015; 135 (4): 305 . doi: 10.4045/tidsskr.15.0176.

44. Russoniello C.V., Fish M.T., O'Brien K. The efficacy of playing videogames compared with antidepressants in reducing treatment-resistant symptoms of depression. Games Health J. 2019. doi: $10.1089 / \mathrm{g} 4 \mathrm{~h} .2019 .0032$

45. Ijaz S., Davies P., Williams C.J., et al. Psychological therapies for treatment-resistant depression in adults. Cochrane Database Syst. Rev. 2018; 5: CD010558. doi: 10.1002/14651858.CD010558.pub2.

46. Любов Е.Б., Зотов П.Б. Диагностика суицидального поведения и оценка степени суицидального риска. Сообщение II. Суииидология. 2018; 2 (31): 16-29. [Lyubov E.B., Zotov P.B. Diagnostics of suicidal behavior and suicide risk evaluation. Report II. Suicidology. 2018; 2 (31): 16-29.] (In Russ)

47. Nakagawa A., Mitsuda D., Sado M., et al. Effectiveness of supplementary cognitive-behavioral therapy for pharmacotherapyresistant depression: a randomized controlled trial. J. Clin. Psychiatry. 2017; 78 (8): 1126-1135. doi: 10.4088/JCP.15m10511.

48. Sargent D.A., Jensen V.W., Petty T.A., Raskin H. Preventing physician suicide. The role of family, colleagues, and organized medicine. JAMA. 1977; 237 (2): 143-145. doi: 10.1001/jama.237.2.143.

49. Pospos S., Young I.T., Downs N., et al. Web-based tools and mobile applications to mitigate burnout, depression, and suicidality among healthcare students and professionals: a systematic review. Acad. Psychiatry. 2018; 42(1): 109-120. doi: 10.1007/s40596-017-0868-0

50. Смиренский Е.А., Смирнова Е.Н., Агафонова А.И. Депрессивные нарушения у студентов медицинского ВУЗа и врачей. Нижегородский психологический альманах. 2018; 2: 175-181. [Smirensky E.A., Smirnova E.N., Agafonova A.I. Depressive disorders in medical students and doctors. Nizhny Novgorod psychological almanac. 2018; 2: 175-181.] (In Russ)

51. Бодагова Е.А., Говорин Н.В. Психическое здоровье врачей разного профиля. Сочиальная и клиническая психиатрия. 2013; 23 (1): 21-26. [Bodagova E.A., Govorin N.V. Mental health of doctors of different profiles. Social and Clinical Psychiatry. 2013; 23 (1): 21-26.] (In Russ)

52. Андреева А.П., Булыгина И.Е., Голенков А.В. Алкогольная зависимость у врачей. XIV съезд психиатров России: Мат. съезда. М., 2005; 326. [Andreeva A.P., Bulygina I.E., Golenkov A.V. Alcohol addiction in doctors]. XIV congress of psychiatrists of Russia: materials of the congress. M., 2005; 326.] (In Russ)

53. Юмагузин В.В., Винник М.В. Оценка реального уровня убийств и самоубийств в регионах России. Сочиологические исследования. 2019; 1: 116-126. [Yumaguzin V.V., Vinnik M.V. Assessment of the real level of murders and suicides in the regions of Russia. Case studies. 2019; 1: 116-126.] (In Russ) 


\title{
SUICIDES AMONG DOCTORS AND HEALTH CARE WORKERS: REVIEW OF LITERATURE
}

\author{
A.V. Filonenko, A.V. Golenkov, V.A. Filonenko, F.V. Orlov, E.S. Deomidov
}

I.N. Ulianov Chuvash State University, Cheboksary, Russia: golenkovav@inbox.ru

Republican Children's Clinical Hospital, Cheboksary, Russia

\section{Abstract:}

According to the World Health Organization, suicide (SU) accounts for almost $1.5 \%$ of all deaths worldwide, and it is one of the 20 main causes of death. Suicidal behavior varies markedly between sexes, age groups and occupational groups, which underlines its possible etiological heterogeneity. The aim of the study was to summarize information about prevalence, factors associated with the risk of SU among doctors and health care workers, as well as the ways to prevent their suicidal behavior. According to different reviews, the level of SU for doctors and health care workers is 1.5-4 times higher than for representatives of a number of other professions and the population at large. Moreover, this is typical for both women and men working in health care. The level of SU for health professionals with easy access to medicines is higher than among those who do not have such an opportunity. It is no coincidence that poisoning is one of the main methods of SU among health care workers. According to this indicator, this professional group is significantly different from the general population. The factors that contribute to SU among doctors and healthcare providers are stress at the workplace, depressive states and other mental disorders (MD), burnout syndrome (BS), low job satisfaction, anhedonia. The prerequisites for the development of depression can be traced from the time of study at university that is further facilitated by professional stresses such as long working hours, lack of sleep, demands for a high degree of professionalism and responsibility for patients, daily conflicts between ethical values and economic goals, as well as lawsuits about negligence (risks of medical errors). In recent decades, doctors' work with patients has become more difficult due to increased workload, administrative responsibilities and reduced autonomy. BS in doctors and healthcare providers depends on specialty (more often among neurologists (53-75\%), surgeons (46$47 \%$ ), obstetrician-gynecologists (45\%), sex (more often among female doctors $-50 \%$ ), weekly workload (the higher, the more common BS is) and lack of respect from patients, administration and colleagues. Economic issues related to the cost of treatment, reduction of public image and uncertainty in the profession, responsibility for terminally ill patients, and strained interpersonal relationships with colleagues affect the perception of job satisfaction. Early detection and proper treatment of major depressive disorder (MD), BS, optimization of interpersonal relationships at work and recognition of the importance of family (immediate environment) support comprise the strategy for prevention of SU among doctors and health care workers. Conclusion. Suicidal behavior is considered a preventable cause of death. Timely psychological and medical treatment can contribute to its prevention. Colleagues' caution about a possible SU, socialization, behavioral, suggestive reflex therapy makes it possible to prevent implementation of suicidal intentions among doctors and health care workers. In Russia, the problem discussed in the review has not been studied much, although the factors contributing to SU are described in the literature. Therefore, there is every reason to talk about an extreme relevance of suicidal behavior and its prevention among members of the medical community of our country.

Keywords: suicide, doctors, health professionals, risk factors, prevention

Вкмад авторов:

А.В. Филоненко: разработка дизайна исследования; написание текста рукописи; редактирование текста рукописи;

A.B. Голенков: $\quad$ написание текста рукописи; редактирование текста рукописи;

B.A. Филоненко: обзор и перевод пубцикаций по теме статьи;

Ф.В. Орлов: обзор публикаций по теме статьи;

E.C. Деомидов: обзор публикаций по теме статьи.

Authors' contributions:

A.V. Filonenko: developing the research design, article writing; article editing;

A.V. Golenkov: article writing; article editing;

V.A. Filonenko: reviewing and translating relevant publications;

F.V. Orlov: $\quad$ reviewing of publications of the article's theme;

E.S. Deomidov: reviewing of publications of the article's theme.

Финансирование: Исследование не имело финансовой поддержки.

Financing: The study was performed without external funding.

Конфмикт интересов: Авторы заявцяют об отсутствии конфмикта интересов.

Conflict of interest: The authors declare no conflict of interest.

Статья поступила / Article received: 29.08.2019. Принята к публикации / Accepted for publication: 08.11.2019.

Для цитирования: Филоненко А.В., Голенков А.В., Филоненко В.А., Орлов Ф.В., Деомидов Е.С. Самоубийства среди врачей и медицинских работников: Обзор литературы. Суицидология. 2019; 10 (3): 42-58. doi.org/10.32878/suiciderus.19-10-03(36)-42-58

For citation: $\quad$ Filonenko A.V., Golenkov A.V., Filonenko V.A., Orlov F.V., Deomidov E.S. Suicides among doctors and health care workers: review of literature. Suicidology. 2019; 10 (3): 42-58. (In Russ)

doi.org/10.32878/suiciderus.19-10-03(36)-42-58 